\title{
Exome sequencing findings in 27 patients with myoclonic-atonic epilepsy: Is there a major genetic factor?
}

\author{
Laura Routier ${ }^{1,2,3}$, Florine Verny ${ }^{1,4}$, Giulia Barcia ${ }^{5}$, Nicole Chemaly ${ }^{1,4}$, Isabelle \\ Desguerre $^{1}$, LaurenceColleaux ${ }^{4}$, Rima Nabbout ${ }^{1,4}$
}

\author{
${ }^{1}$ Reference Centre for Rare Epilepsies, \\ Pediatric Neurology, Necker Enfants-Malades \\ Hospital, Paris, France \\ ${ }^{2}$ Pediatric Neurology, Amiens-Picardie \\ University Hospital, Amiens, France \\ ${ }^{3}$ GRAMFC-INSERM U1105, UPJV, Amiens, \\ France \\ ${ }^{4}$ INSERM UMR1163, Translational Research \\ for Neurological Disorders, Imagine Institute, \\ Paris-Descartes University, Paris, France \\ ${ }^{5}$ Clinical Genetics, Necker Enfants-Malades \\ Hospital, Paris, France \\ Correspondence \\ Reference Centre for Rare Epilepsies, Pediatric \\ Neurology, Necker Enfants-Malades Hospital, \\ Paris, France. \\ Email: routier.laura@chu-amiens.fr \\ Funding information \\ Fondations Maladies Rares (France)
}

\begin{abstract}
Myoclonic-atonic epilepsy (MAE) is thought to have a genetic etiology. Mutations in CHD2, SLC2A1 and SLC6A1 genes have been reported in few patients showing often intellectual disability prior to MAE onset. We aimed to explore putative causal genetic factors in MAE. We performed array-CGH and whole-exome sequencing in 27 patients. We considered non-synonymous variants, splice acceptor, donor site mutations, and coding insertions/deletions. A gene was causal when its mutations have been already linked to epilepsy or other brain diseases or when it has a putative function in neuronal excitability or brain development. We identified candidate disease-causing variants in 11 patients (41\%). Single variants were found in some known epilepsy-associated genes (namely CHD2, KCNT1, KCNA2 and STXBP1) but not in others (SLC2A1 and SLC6A1). One new candidate gene SUN1 requires further validation. MAE shows underlying genetic heterogeneity with only few cases linked to mutations in genes reported in developmental and epileptic encephalopathies.
\end{abstract}

KE YWOR DS

Doose syndrome, epileptic encephalopathy, exome sequencing, genes, myoclonic-atonic epilepsy

\section{1 | INTRODUCTION}

Myoclonic-atonic epilepsy (MAE) is a rare epileptic encephalopathy estimated to account for $1 \%$ to $2 \%$ of childhood-onset epilepsies. ${ }^{1,2}$ MAE is diagnosed in a child with normal development, with onset of myoclonic, myoclonic-atonic or atonic seizures between 7 months and 6 years old and generalized spike or polyspike-wave discharges on the electroencephalogram (EEG). ${ }^{3}$

The cause of MAE has yet to be determined. However, high incidence of epilepsy in patients' family ${ }^{1,2,4,5}$ and a higher prevalence among patients' relatives (200 times higher than in the general population $)^{2}$ suggest a genetic basis. Some genes have been linked to sporadic cases of MAE: SLC2A1, SLC6A1, CHD2, SCN1A, GABRG2,
SCN2A, CACNA1H, SYNGAP1 and SCN1B.,6-14 Many of the patients presented a pre-existing intellectual disability (ID) therefore showing atypical clinical presentation ${ }^{15}$ (Table 1 ). To identify possible major genetic factors, we performed array-comparative genomic hybridization $(\mathrm{CGH})$ and whole-exome sequencing (WES) in 27 patients with typical MAE.

\section{2 | MATERIALS AND METHODS}

\section{1 | Patients}

We included 22 males and 5 females with MAE, without structural brain lesion or underlying metabolic diseases. Age of onset ranged 
TA BLE 1 Clinical and electroencephalographic features of previously reported MAE cohorts with an identified mutation

\begin{tabular}{|c|c|c|c|c|c|}
\hline Gene & $\begin{array}{l}\text { Number of } \\
\text { patients with } \\
\text { the mutation }\end{array}$ & $\begin{array}{l}\text { Age at onset of } \\
\text { seizures }\end{array}$ & $\begin{array}{l}\text { Development before the onset } \\
\text { of epilepsy }\end{array}$ & Electroencephalographic main features & Authors \\
\hline$S L C 2 A 1$ & 4 & $\begin{array}{l}26.6 \text { months } \\
(8-48)\end{array}$ & Delayed for 3 of the 4 & Typical: generalized SW or PSW & Mullen et al. $2011^{12}$ \\
\hline SLC6A1 & 7 & $\begin{array}{l}24.7 \text { months } \\
(12-36)\end{array}$ & Delayed for all 7 & $\begin{array}{l}\text { Atypical: SW on eye closure, PPR, continuous } \\
\text { SW discharges during sleep, atypical } \\
\text { absences, hyperventilation-provoked } \\
\text { subclinical paroxysms } \\
\text { Typical: generalized SW or PSW, slow } \\
\text { background activity }\end{array}$ & Carvill et al. $2015^{4}$ \\
\hline CHD2 & 1 & 41 months & Normal & $\begin{array}{l}\text { Atypical: PPR } \\
\text { Typical: generalized SW wave, slow } \\
\text { background activity }\end{array}$ & Trivisano et al. $2015^{6}$ \\
\hline GABRG2 & 1 & Not reported & Not reported & Not reported & Wallace et al. $2001^{8}$ \\
\hline CACNA1H & 4 & Not reported & Not reported & Not reported & Heron et al. $2007^{9}$ \\
\hline SCN1B & 1 & Not reported & Not reported & Not reported & Wallace et al. $1998^{7}$ \\
\hline$S C N 2 A$ & 2 & $\begin{array}{l}15 \text { and } \\
24 \text { months }\end{array}$ & $\begin{array}{l}\text { Delayed in one and Normal in } \\
\text { the other }\end{array}$ & $\begin{array}{l}\text { Typical: generalized SW, slow background } \\
\text { activity }\end{array}$ & Wolff et al. $2017^{14}$ \\
\hline SYNGAP1 & 3 (MAE like) & $\begin{array}{l}\text { 22, } 24 \text { and }<24 \\
\text { months }\end{array}$ & Delayed for all 3 & $\begin{array}{l}\text { Atypical: PPR, focal spike wave } \\
\text { Typical: generalized SW and PSW }\end{array}$ & Mignot et al. $2016^{13}$ \\
\hline
\end{tabular}

Abbreviations: MAE, myoclonic-atonic epilepsy; PPR, photoparoxysomal response, PSW, polyspike-waves, SW, spike-waves.

from 1.5 to 5.6 years. All patients had at least 5 years follow-up after the onset. Patients' legal guardians provided written informed consent. The Cochin-Port-Royal Hospital Investigational Review Board (France) approved the study.

\subsection{Array-CGH and WES}

Genomic DNA was extracted from peripheral blood using a standard procedure. We first performed array-CGH by $60 \mathrm{~K}$ oligonucleotide microarray (Agilent Technologies, Santa Clara, California) according to the manufacturer's recommendations.

Exome capture was performed by the SureSelectXT Human All Exon V3 $50 \mathrm{Mb}$ target-enrichment kit (Agilent Technologies, Massy, France) in trios (proband and parents). Sequencing was performed using a paired-end strategy and an average read length of 75 bases and average coverage of $130 \times$ (Illumina HISEQ, Illumina Inc., San Diego, California). Sequences were aligned to the human genome reference sequence (hg19 assembly) with the Burrows-Wheeler Aligner (Illumina).

Downstream processing was carried out with the Genome Analysis Toolkit (GATK), ${ }^{17}$ SAMtools ${ }^{18}$ and Picard Tools. An in-house pipeline performed genetic variation annotation.

\section{3 | WES analysis}

Trio analysis was performed considering all Mendelian inheritance models. We excluded common genetic variants already described in public or in-house datasets with allelic frequencies $>0.01$. We focused on nonsynonymous variants, splice acceptor and donor site variants or coding indels. Sanger sequencing confirmed all retained variants.

\section{3 | RESULTS}

Two patients (7 and 10) had a family history of febrile seizures that resolved by the age of 5 years with no further epilepsy, neurologic or psychiatric disorders. Array-CGH showed a 575-kb de novo duplication in 5 q22.3 in one patient with no relevant epilepsies genes included in this interval. He showed moderate ID during follow-up.

WES highlighted a candidate disease-causing gene in 11 patients (41\%). Five patients (19\%) had mutations in epilepsy genes but not the other six (22\%). 36\% were de novo, $18 \%$ X-linked and $36 \%$ showed recessive inheritance (Table 2). We classified these mutations as causal, highly probable or probable candidates (Table 3 ). 
TA BLE 2 Identified, selected mutations and inheritance using whole-exome sequencing (WES) in our cohort

\begin{tabular}{|c|c|c|c|c|c|c|c|c|c|}
\hline Proband & Sex & $\mathrm{CGH}$ & Gene & Inheritance & Mutation & $\begin{array}{l}\text { Previous descriptions } \\
\text { in public databases }\end{array}$ & $\begin{array}{l}\text { PolyPhen-2 } \\
\text { (HumVar) }\end{array}$ & SIFT & Mutation taster \\
\hline \multicolumn{10}{|c|}{ Genes already reported in patients with MAE } \\
\hline \multirow[t]{2}{*}{10} & \multirow[t]{2}{*}{$\mathrm{MN}$} & & \multirow{2}{*}{\multicolumn{2}{|c|}{ CACNA1HCH }} & $\begin{array}{l}\text { NM_021098.2: } \\
\text { c.3283G > A; p. } \\
\text { Asp1095Asn }\end{array}$ & EXAC & $\begin{array}{l}\text { Probably } \\
\text { damaging } \\
\text { (Score: } 1 \text { ) }\end{array}$ & $\begin{array}{l}\text { Deleterious } \\
\quad(0.03)\end{array}$ & $\begin{array}{l}\text { Disease-causing } \\
\quad(P \text {-value: .955) }\end{array}$ \\
\hline & & & & & $\begin{array}{l}\text { NM_021098.2: } \\
\text { c.4756A > G; p. } \\
\text { Arg1586Gly }\end{array}$ & $\begin{array}{l}\text { ExAC and Variants } \\
\text { dbSNP }\end{array}$ & $\begin{array}{l}\text { Probably } \\
\text { damaging } \\
\text { (Score: } 0,979 \text { ) }\end{array}$ & $\begin{array}{l}\text { Deleterious } \\
\quad(0)\end{array}$ & $\begin{array}{l}\text { Disease-causing } \\
(P \text {-value: .984) }\end{array}$ \\
\hline \multicolumn{10}{|c|}{ Genes already reported in other epilepsies and in Developmental epileptic encephalopathies } \\
\hline 6 & M & $\mathrm{N}$ & KCNT1 & de novo & $\begin{array}{l}\text { NM_020822.2: } \\
\text { c.862G > A; } p . \\
\text { Gly288Ser }\end{array}$ & ClinVar & $\begin{array}{l}\text { Probably } \\
\text { damaging } \\
\text { (score:0.978) }\end{array}$ & $\begin{array}{c}\text { Tolerated } \\
\text { (score: } \\
0.26)\end{array}$ & $\begin{array}{l}\text { Disease-causing } \\
(P \text {-value: } 1)\end{array}$ \\
\hline 9 & M & $\mathrm{N}$ & $M E C P 2^{\mathrm{a}}$ & MI & $\begin{array}{l}\text { NM_001110792.1: } \\
\text { c.259C > A;p.Pro87Thr }\end{array}$ & - & $\begin{array}{l}\text { Possibly } \\
\text { damaging } \\
(0,794)\end{array}$ & $\begin{array}{l}\text { Deleterious } \\
\text { (score: } 0 \text { ) }\end{array}$ & $\begin{array}{l}\text { Disease-causing } \\
(P \text {-value: } 1)\end{array}$ \\
\hline \multicolumn{10}{|c|}{ Genes reported in neurodevelopmental disorders } \\
\hline 3 & M & $\mathrm{N}$ & SHROOM & Not tested & $\begin{array}{l}\text { NM_020717.3: } \\
\text { c.1201C > T; p. } \\
\text { His401Tyr }\end{array}$ & Variants dbSNP, ExAC & Benign $(0,410)$ & $\begin{array}{l}\text { Deleterious } \\
\quad(0.05)\end{array}$ & $\begin{array}{l}\text { Disease-causing } \\
(P \text {-value: .589) }\end{array}$ \\
\hline \multirow[t]{2}{*}{2} & \multirow[t]{2}{*}{$\mathrm{F}$} & \multirow[t]{2}{*}{$\mathrm{N}$} & \multirow[t]{2}{*}{$T P P 1^{\mathrm{a}}$} & \multirow[t]{2}{*}{$\mathrm{CH}$} & $\begin{array}{l}\text { NM_000391.3(TPP1): } \\
\text { c.509-1G> }\end{array}$ & - & \multicolumn{2}{|c|}{$\begin{array}{l}\text { Essential splicing Essential } \\
\text { splicing }\end{array}$} & Essential splicing \\
\hline & & & & & $\begin{array}{l}\text { NM_000391.3(TPP1): } \\
\text { c.622C > T; p.Arg208 }\end{array}$ & $\begin{array}{l}\text { ExAC, ClinVar, } \\
\text { COSMIC, ESP }\end{array}$ & Stop-gained & Stop-gained & Stop-gained \\
\hline \multicolumn{10}{|c|}{ Gene not reported in neurological diseases } \\
\hline \multirow[t]{2}{*}{11} & \multirow[t]{2}{*}{$M$} & \multirow[t]{2}{*}{$\mathrm{N}$} & \multirow[t]{2}{*}{ SUN $1^{a}$} & \multirow[t]{2}{*}{$\mathrm{CH}$} & $\begin{array}{l}\text { NM_001130965:c.1779 } \\
+2 \_1779+\text { 9dup; p.? }\end{array}$ & - & $\begin{array}{l}\text { Splicing } \\
\text { frameshift }\end{array}$ & $\begin{array}{l}\text { Splicing } \\
\text { frameshift }\end{array}$ & $\begin{array}{l}\text { Splicing } \\
\text { frameshift }\end{array}$ \\
\hline & & & & & $\begin{array}{l}\text { NM_001130965: } \\
\text { c.956C > G; p. } \\
\text { Pro319Arg }\end{array}$ & - & $\begin{array}{l}\text { Probably } \\
\text { damaging } \\
\text { (Score: } 1 \text { ) }\end{array}$ & $\begin{array}{l}\text { Tolerated } \\
\qquad(0.15)\end{array}$ & $\begin{array}{l}\text { Disease-causing } \\
\quad(P \text {-value: } 1)\end{array}$ \\
\hline
\end{tabular}

Abbreviations: $\mathrm{CH}$, compound heterozygous; F, female; M, male; MI, maternally inherited; N, normal; UTR, untranslated transcribed region. ${ }^{\text {a }}$ Autism spectrum disorder.

\subsection{Genes already reported in MAE}

A de novo CHD2 missense variant (NM_001271.3:c.1861C > T;p. Arg621Trp) was identified in Patient 7. Proband 10 had compound heterozygous variants in CACNA1H (NM_021098.2:c.3283G > A;p. Asp1095Asn and.

$$
\text { NM_021098.2:c.4756A > G;p.Arg1586Gly). }
$$

\subsection{Genes reported in other epilepsies}

A de novo missense KCNA2 variant (NM_004974.3:c.889C > T; p.Arg297Trp) was found in Patient 5. Another mutation affecting the same codon (c.890G > A;p.Arg297Gln) had already been linked to developmental and epileptic encephalopathies (DEE). ${ }^{33}$ 
TAB LE 3 Selection of variants as pathogenic or potentially damaging

\begin{tabular}{|c|c|c|c|c|c|c|c|c|}
\hline Gene & Reported in MAE & $\begin{array}{l}\text { Reported in other } \\
\text { epilepsies }\end{array}$ & $\begin{array}{l}\text { Associated with } \\
\text { neurodevelopmental } \\
\text { disorders }\end{array}$ & $\begin{array}{l}\text { Proteins expressed in } \\
\text { brain/reported in } \\
\text { animal model }\end{array}$ & $\begin{array}{l}\text { Function of the } \\
\text { encoded protein }\end{array}$ & $\begin{array}{l}\text { Described neurological } \\
\text { pathologies }\end{array}$ & Known IM & $\begin{array}{l}\text { Suspected } \\
\text { IM in our } \\
\text { cohort }\end{array}$ \\
\hline CHD2 & $\begin{array}{l}\text { Carvill et al. } \\
2013,{ }^{\prime y} \\
\text { Trivisano et al. } \\
2015^{6}\end{array}$ & $\begin{array}{l}\text { Carvill et al. } 2013,{ }^{1 y} \\
\text { Trivisano et al. } \\
2015^{\circ}\end{array}$ & $\begin{array}{l}\text { Carvill et al. } 2013,,^{19} \\
\text { Trivisano et al. } \\
2015^{\circ}\end{array}$ & Trivisano et al. $2015^{6}$ & $\begin{array}{l}\text { DNA recombination } \\
\text { and cell-cycle } \\
\text { regulation }\end{array}$ & $\begin{array}{l}\text { atypical DS, LGS, Jeavons } \\
\text { syndrome and MAE }\end{array}$ & $A D$ & $A D$ \\
\hline CACNA1H & Heron et al. $2007^{y}$ & Heron et al. $2007^{y}$ & $\begin{array}{l}\text { Heron et al. 2007, } \\
\text { Splawski et al. } \\
2006^{20}\end{array}$ & $\begin{array}{l}\text { Heron et al. } 2007,{ }^{y} \\
\text { Splawski et al. } 2006^{<u}\end{array}$ & $\begin{array}{l}\text { T-type calcium } \\
\text { channel }\end{array}$ & $\begin{array}{l}\text { absence epilepsy, idiopathic } \\
\text { generalized epilepsy, } \\
\text { febrile seizures and MAE }\end{array}$ & $A D$ & AR \\
\hline KCNA2 & - & Syrbe et al. $2015^{21}$ & Syrbe et al. $2015^{21}$ & Syrbe et al. $2015^{21}$ & $\begin{array}{l}\text { Voltage-gated } \\
\text { potassium channel }\end{array}$ & early childhood onset EE & $A D$ & $A D$ \\
\hline STXBP1 & - & $\begin{array}{l}\text { Saitsu et al. } 2008,^{22} \\
\text { Stamberger et al. } \\
2016^{23}\end{array}$ & $\begin{array}{l}\text { Saitsu et al. } 2008^{22} \\
\text { Stamberger et al. } \\
2016^{23}\end{array}$ & $\begin{array}{l}\text { Saitsu et al. } 2008^{22} \\
\text { Stamberger et al. } \\
2016^{23}\end{array}$ & $\begin{array}{l}\text { Regulation of synaptic } \\
\text { vesicle docking and } \\
\text { fusion }\end{array}$ & $\begin{array}{l}\text { EE, infantile spasms, LGS, ID } \\
\text { and fever sensitive } \\
\text { epilepsies }\end{array}$ & $A D$ & $A D$ \\
\hline KCNT1 & - & Barcia et al. $2012^{24}$ & Barcia et al. $2012^{24}$ & Barcia et al. $2012^{24}$ & $\begin{array}{l}\text { Sodium-activated } \\
\text { potassium channel }\end{array}$ & $\begin{array}{l}\text { EIMFS and nocturnal frontal } \\
\text { lobe epilepsy }\end{array}$ & $A D$ & $A D$ \\
\hline MECP2 & - & Villard $2007^{25}$ & Villard $2007^{25}$ & Villard $2007^{25}$ & $\begin{array}{l}\text { Connection and } \\
\text { synapticregulation }\end{array}$ & $\begin{array}{l}\text { Rett syndrome and severe } \\
\text { ID }\end{array}$ & X-linked & X-linked \\
\hline SHROOM4 & - & - & $\begin{array}{l}\text { Hagens et al. } 2006,{ }^{26} \\
\text { Yoder and } \\
\text { Hildebrand } 2007^{27}\end{array}$ & $\begin{array}{l}\text { Hagens et al. } 2006,{ }^{26} \\
\text { Yoder and } \\
\text { Hildebrand } 2007^{27}\end{array}$ & $\begin{array}{l}\text { Cytoskeletal } \\
\text { architecture } \\
\text { regulation }\end{array}$ & X-linked ID & X-linked & - \\
\hline FTSJ1 & - & - & $\begin{array}{l}\text { Ramser et al. 2004, } \\
\text { Freude et al. } 2004^{29}\end{array}$ & $\begin{array}{l}\text { Ramser et al. } 2004^{28} \\
\text { Freude et al. } 2004^{29}\end{array}$ & $\begin{array}{l}\text { Supposed translation } \\
\text { regulation }\end{array}$ & X-linked ID & X-linked & X-linked \\
\hline TPP1 & - & - & Sun et al. $2013^{30}$ & Sun et al. $2013^{30}$ & $\begin{array}{l}\text { Lysosomal serine } \\
\text { protease }\end{array}$ & $\begin{array}{l}\text { ceroid lipofuscinosis } 2 \text { and } \\
\text { spinocerebellar ataxia }\end{array}$ & AR & AR \\
\hline$K L C 2$ & - & - & - & Melo et al. $2015^{31}$ & $\begin{array}{l}\text { Anterograde } \\
\text { axoplasmatic } \\
\text { transport }\end{array}$ & $\begin{array}{l}\text { spastic paraplegia, optic } \\
\text { atrophy and neuropathy }\end{array}$ & AR & $A R$ \\
\hline SUN1 & - & - & - & Zhang et al. $2009^{32}$ & $\begin{array}{l}\text { Neurogenesis and } \\
\text { interkinetic nuclear } \\
\text { migration }\end{array}$ & - & - & - \\
\hline
\end{tabular}

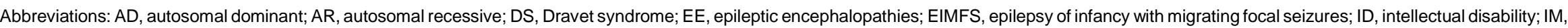
inheritance mode; LGS, Lennox-Gastaut syndrome; MAE, myoclonic-atonic epilepsy. 
Proband 8 carried a de novo variant in STXBP1 (NM_003165.3: c. $288 \mathrm{~T}>\mathrm{C})$.

A de novo KCNT1 mutation (NM_020822.2:c.862G > A;p.Gly288Ser) previously described in epilepsy of infancy with migrating focal seizures (EIMFS) and in autosomal dominant nocturnal frontal lobe epilepsy (ADNFLE) was found in proband6. ${ }^{24,34}$

Lastly, proband 9 showed a maternally inherited MECP2 variant (NM_001110792.1:c.259C > A;p.Pro87Thr) that alters a conserved amino acid.

\section{3 | Genes reported in neurodevelopmental disorders}

Four strong candidates genes have already been linked to autism spectrum disorder (ASD), ID and neurodegenerative brain disease (Table 3). Variants in SHROOM4 (NM_020717.3:c.1201C > T; p. His401Tyr) and FTSJ1 (NM_012280.3:C. ${ }^{*} 9+1 \mathrm{G}>\mathrm{T}$ ) were identified. A missense mutation (NM_001134775.1:c.1295G > A;p.Gly432Glu) was combined with an intronic mutation (patient 4) (NM_001134775.1;C.1785 + 42G > T) in KCL2.

Patient 2 had a nonsense mutation (NM_000391.3:c.622C > T;p. Arg208*) and a splice variant (NM_000391.3:c.509-1G>) in TPP1 (already linked to ceroid lipofuscinosis 2 and autosomal recessive spinocerebellar ataxia). ${ }^{30,35}$

\section{4 | Probable candidate gene not reported in known central nervous system diseases}

Proband 11 showed a compound heterozygous variants in SUN1, with a missense mutation (NM_001130965:c.956C > G;p.Pro319Arg) and a splice variant (NM_001130965:c.1779 + 2_1779 + 9dup). SUN1 is involved in neurogenesis, nuclear connections and interkinetic migration. $^{35}$

\subsection{ID and ASD during follow-up}

All patients (1-11) with reported genes showed moderate ID during follow-up. ASD was present in six patients (Table 2). In patients with no reported mutations, ID was reported in $25 \%$ and ASD in $15 \%$.

\section{4 | DISCUSSION}

The present study reports WES results in a cohort of MAE. We found mutations in epilepsy genes in only $19 \%$ of cases but we did not replicate the high prevalence of mutations in SLC2A1 or SLC6A1.,12 Our results highlighted the genetic heterogeneity of MAE phenotype and extended it to causal genes inDEE.

We found pathogenic variants in two genes previously linked to MAE. CHD2 is reported in MAE, atypical Dravet syndrome (DS), Lennox-Gastaut syndrome (LGS) and Jeavons syndrome., ${ }^{6,15,19}$ Patients present common characteristics as previous developmental delay, fever and photosensitivity. Myoclonic seizures and ASD are often reported. ${ }^{6,15}$ Our patient did not present these characteristics extending the phenotypic spectrum of CHD2 mutations to typical MAE.

Mutations in CACNA1H were described in a few patients with $\mathrm{MAE},{ }^{9}$ but also in patients with ASD and generalized epilepsy. ${ }^{9,20}$ The co-existence of two compound heterozygous variants in patient 10 might suggest that $C A C N A 1 H$ is causal.

We extended the spectrum of genes reported in epilepsies and mainly in DEE to typical MAE phenotype as KCNA2, STXBP1 and $K C N T 1^{22,23,36}$ The mutation reported in KCNT1 was already reported in both major phenotypes, EIFMS and ADNFLE. ${ }^{24,34} \mathrm{~A}$ few patients were reported with Ohtahara syndrome. Mutations in MECP2 in males are responsible for severe $I^{25}$ with rarely reported epilepsy. The normal development still the age of 18 months could question the causality of this mutation, however, the known phenotype spectrum of many developmental genes and the pathogenic nature of the variant allowed us to hypothesize a causal effect in this patient.

Lastly, we identified the genes SHROOM4, FTSJ1, TPP1, KLC2 and SUN1 as strong new candidates. SHROOM4 and FTSJ1 mutations have been reported in neurological impairments, including $X$ linked ID. ${ }^{26,28} K L C 2$ mutations have been reported in neurodegenerative disorder combining spastic paraplegia, optic atrophy and neuropathy. ${ }^{31,35}$

We had difficulty analyzing significant variants in SUN1 expressed in the nervous system and not previously reported in brain diseases. Its involvement in MAE needs to be confirmed by further case studies and functional investigations.

Finally, all patients with epilepsy genes or genes reported in neurodevelopmental disorders showed ID and some presented later ASD. This higher incidence of ID and ASD compared to the group with no identified genes might be related to the direct developmental impact of these genes beyond seizures and EEG impact. The normal development before the epilepsy onset is interesting in this cohort and is similar to a few patients reported with DEE genes and a normal neurological development before epilepsy onset.

This study reaffirms that copy number variation accounts for a small proportion of MAE as for Genetic (idiopathic) generalized epilepsies. ${ }^{37,38}$ MAE might be considered as a heterogeneous condition as infantile spasms or LGS with few monogenic cases and with others possible multigenic, epigenetic and/or environmental factors involved in the emergence of MAE.

The identification of rare but treatable etiologies as Glut1 deficiency is to be emphasized although we did not find this mutation in our series. The lack of a major causal gene raises major questions on the homogeneity of this electro-clinical phenotype with in some reports the use of "MAE-like" phenotype.

Finally, our data emphasize the difficulty to establish the causal role of variants even in homogeneous cohorts. The larger use of WES that is increasingly replacing gene panels should help accumulating data from phenotyped cohorts to broaden the spectrum of known genes and helping to discover new causal genes. 


\section{ACKNOWLEDGEMENTS}

This work was funded in part by a grant from Fondation Maladies Rares (France).

\section{CONFLICT OF INTEREST}

We declare no conflict of interest.

\section{DATA ACCESSIBILITY}

Data available on request from the authors

\section{REFERENCES}

1. Tang S, Pal DK. Dissecting the genetic basis of myoclonic-astatic epilepsy. Epilepsia. 2012;53:1303-1313.

2. Kelley SA, Kossoff EH. Doose syndrome (myoclonic-astatic epilepsy): 40 years of progress. Dev Med Child Neurol. 2010;52:988-993.

3. Proposal for revised classification of epilepsies and epileptic syndromes. Commission on classification and terminology of the international league against epilepsy. Epilepsia. 1989;30:389-399.

4. Carvill GL, McMahon JM, Schneider A, et al. Mutations in the GABA transporter SLC6A1 cause epilepsy with myoclonic-atonic seizures. Am J Hum Genet. 2015;96:808-815.

5. Kaminska A, Ickowicz A, Plouin P, Bru MF, Dellatolas G, Dulac O. Delineation of cryptogenic Lennox-Gastaut syndrome and myoclonic astatic epilepsy using multiple correspondence analysis. Epilepsy Res. 1999;36:15-29.

6. Trivisano M, Striano P, Sartorelli J, et al. CHD2 mutations are a rare cause of generalized epilepsy with myoclonic-atonic seizures. Epilepsy Behav. 2015;51:53-56.

7. Wallace RH, Wang DW, Singh R, et al. Febrile seizures and generalized epilepsy associated with a mutation in the $\mathrm{Na+-}$-channel beta1 subunit gene SCN1B. Nat Genet. 1998;19:366-370.

8. Wallace $\mathrm{RH}$, Marini $\mathrm{C}$, Petrou $\mathrm{S}$, et al. Mutant GABA(a) receptor gamma2-subunit in childhood absence epilepsy and febrile seizures. Nat Genet. 2001;28:49-52.

9. Heron SE, Khosravani H, Varela D, et al. Extended spectrum of idiopathic generalized epilepsies associated with CACNA1H functional variants. Ann Neurol. 2007;62:560-568.

10. Dimova PS, Yordanova I, Bojinova V, Jordanova A, Kremenski I. Generalized epilepsy with febrile seizures plus: novel SCN1A mutation. Pediatr Neurol. 2010;42:137-140.

11. Yordanova I, Todorov T, Dimova $P$, et al. One novel Dravet syndrome causing mutation and one recurrent MAE causing mutation in SCN1A gene. Neurosci Lett. 2011;494:180-183.

12. Mullen SA, Marini C, Suls A, et al. Glucose transporter 1 deficiency as a treatable cause of myoclonic astatic epilepsy. Arch Neurol. 2011;68: 1152-1155.

13. Mignot C, von Stulpnagel C, Nava C, et al. Genetic and neurodevelopmental spectrum of SYNGAP1-associated intellectual disability and epilepsy. J Med Genet.2016;53:511-522.

14. Wolff M, Johannesen KM, Hedrich UBS, et al. Genetic and phenotypic heterogeneity suggest therapeutic implications in SCN2Arelated disorders. Brain. 2017;140:1316-1336.

15. Carvill G, Helbig I, Mefford H. CHD2-related neurodevelopmental disorders. In: Pagon RA, Adam MP, Ardinger $\mathrm{HH}$, et al., eds. Seattle, WA: GeneReviews; 1993.

16. Dimova EY, Kietzmann T. Hypoxia-inducible factors: posttranslational crosstalk of signaling pathways. Methods Mol Biol. 2010; 647:215-236.

17. McKenna A, Hanna M, Banks E, et al. The genome analysis toolkit: a MapReduce framework for analyzing next-generation DNA sequencing data. Genome Res. 2010;20:1297-1303.

18. Li H, Handsaker B, Wysoker A, et al. 1000 Genome Project Data Processing Subgroup The sequence alignment/map format and SAMtools. Bioinformatics. 2009;25:2078-2079.

19. Carvill GL, Heavin SB, Yendle SC, et al. Targeted resequencing in epileptic encephalopathies identifies de novo mutations in CHD2 and SYNGAP1. Nat Genet. 2013;45:825-830.

20. Splawski I, Yoo DS, Stotz SC, Cherry A, Clapham DE, Keating MT. CACNA1H mutations in autism spectrum disorders. $J$ Biol Chem. 2006;281:22085-22091.

21. Syrbe S, Hedrich UB, Riesch E, et al. De novo loss- or gain-of-function mutations in KCNA2 cause epileptic encephalopathy. Nat Genet. 2015;47:393-399.

22. Saitsu $H$, Kato M, Mizuguchi T, et al. De novo mutations in the gene encoding STXBP1 (MUNC18-1) cause early infantile epileptic encephalopathy. Nat Genet. 2008;40:782-788.

23. Stamberger $\mathrm{H}$, Nikanorova $\mathrm{M}$, Willemsen $\mathrm{MH}$, et al. STXBP1 encephalopathy: a neurodevelopmental disorder including epilepsy. Neurology. 2016;86:954-962.

24. Barcia G, Fleming MR, Deligniere A, et al. De novo gain-of-function KCNT1 channel mutations cause malignant migrating partial seizures of infancy. Nat Genet. 2012;44:1255-1259.

25. Villard L. MECP2 mutations in males. J Med Genet. 2007;44:417-423.

26. Hagens O, Dubos A, Abidi F, et al. Disruptions of the novel KIAA1202 gene are associated with X-linked mental retardation. Hum Genet. 2006;118:578-590.

27. Yoder M, Hildebrand JD. Shroom4 (Kiaa1202) is an actin-associated protein implicated in cytoskeletal organization. Cell Motil Cytoskeleton. 2007;64:49-63.

28. Ramser J, Winnepenninckx B, Lenski C, et al. A splice site mutation in the methyltransferase gene FTSJ1 in Xp11.23 is associated with nonsyndromic mental retardation in a large Belgian family (MRX9). J Med Genet. 2004;41:679-683.

29. Freude K, Hoffmann K, Jensen LR, et al. Mutations in the FTSJ1 gene coding for a novel S-adenosylmethionine-binding protein cause nonsyndromic X-linked mental retardation. Am J Hum Genet. 2004;75: 305-309.

30. Sun Y, Almomani R, Breedveld GJ, et al. Autosomal recessive spinocerebellar ataxia 7 (SCAR7) is caused by variants in TPP1, the gene involved in classic late-infantile neuronal ceroid lipofuscinosis 2 disease (CLN2 disease). Hum Mutat. 2013;34:706-713.

31. Melo US, Macedo-Souza LI, Figueiredo T, et al. Overexpression of $\mathrm{KLC} 2$ due to a homozygous deletion in the non-coding region causes SPOAN syndrome. Hum Mol Genet.2015;24:6877-6885.

32. Zhang $X$, Lei K, Yuan $X$, et al. SUN1/2 and Syne/Nesprin-1/2 complexes connect centrosome to the nucleus during neurogenesis and neuronal migration in mice. Neuron. 2009;64:173-187.

33. Pena SDJ, Coimbra RLM. Ataxia and myoclonic epilepsy due to a heterozygous new mutation in KCNA2: proposal for a new channelopathy. Clin Genet. 2015;87:e1-e3.

34. Ishii $A$, Shioda M, Okumura A, et al. A recurrent KCNT1 mutation in two sporadic cases with malignant migrating partial seizures in infancy. Gene. 2013;531:467-471.

35. Elleder M, Dvorakova L, Stolnaja L, et al. Atypical CLN2 with later onset and prolonged course: a neuropathologic study showing different sensitivity of neuronal subpopulations to TPP1 deficiency. Acta Neuropathol. 2008;116:119-124. 
36. Hamdan FF, Piton A, Gauthier J, et al. De novo STXBP1 mutations in mental retardation and nonsyndromic epilepsy. Ann Neurol. 2009;65:748-753.

37. Epilepsy Phenome/Genome Project Epi KC. Copy number variant analysis from exome data in 349 patients with epileptic encephalopathy. Ann Neurol. 2015;78:323-328.

38. Mullen SA, Berkovic SF, the ILAE Genetics Commission. Genetic generalized epilepsies. Epilepsia. 2018;59:1148-1153. 